\title{
The Utility of Social Media during an Emerging Infectious Diseases Crisis: A Systematic Review of Literature
}

\author{
Amit Agrawal ${ }^{1}$, Ankita Gupta ${ }^{2}$ \\ ${ }^{1}$ Department of Pediatrics, Gandhi Medical College \& Hamidia Hospital, Bhopal, MP, India \\ ${ }^{2}$ Public Health Dentistry, Rishiraj College of Dental Sciences, Bhopal, MP, India \\ These two authors contributed equally to this article
}

\begin{abstract}
Objectives: The use of social networking sites for monitoring emerging infectious diseases (EIDs) are on rise. This systematic review examines the available evidence supporting and refuting the use of social media in communicating with the public during the pandemic outbreaks of infectious disease, influencing people's behavior, spreading the awareness, and creating or dispelling rumors.
\end{abstract}

Methods: PubMed, Google Scholar, and Cochrane Library databases were systematically searched from 2012 till 2019 for studies on the use of social media in detecting the following EIDs: the Ebola virus, Zika virus, Nipah virus, West Nile, Bird flu and Swine flu. The included studies were evaluated and data were extracted and reviewed.

Results: Preliminary search results showed that out of 6224 articles related to social media and EIDs, 49 articles were related to our study objectives. Out of 49 articles, most of the articles were related to the Zika virus ( $n=24)$, published in $2017(n=15)$ and utilized the Twitter social media $(n=26)$.

Conclusion: The present systematic review supports the use of social media as an important medium for the clinicians, public health practitioners, and laypeople seeking health information for the detection of EIDs. $J$ Microbiol Infect Dis 2020; 10(4):188-198.

Keywords: Emerging diseases, Infectious diseases, Information technology, Social media

\section{INTRODUCTION}

Emerging infectious diseases (EIDs) are of particular concern to public health. The term was first coined by Lederberg et al [1]. EIDs refer to those new infectious diseases that appeared in the last 20 years. The common route of transmission of EIDs is through insects, water, animals, or from person-to-person but $75 \%$ of the EIDs that have affected humans over the last three decades are of zoonotic origin, i.e. they spread from animals to humans [2].

A rise in these outbreaks also coincided with the increased use of social media as a source of public health information [3,4]. Obar and Wildman (2015) defines the social media as "the services that are based on web 2.0 technologies and largely rely on the user-generated content, by which individuals and organizations create profiles, and develop social networks online" [5].
According to the WHO, $51 \%$ of the outbreak information related to EIDs was obtained initially from the media sources between 2001 and 2011 [6]. Over the last decade, social media has become a potential tool to predict infectious disease outbreaks across the world and reached far beyond the traditional surveillance system. A systematic review conducted by Korda and Itani has shown the ways through which social media can be applied for promoting health by providing information access, delivering health campaigns, and offering social support [7].

Although social media has uncountable benefits for detecting the EID outbreaks, the generalizability and reliability for all searches are unpredictable as people may not be searching the top posts alone, and misleading information may also be present along with the reliable information, which can misguide the users. Hence, the present systematic review was

Correspondence: Dr. Ankita Gupta, Senior Lecturer, Public Health Dentistry, Rishiraj College of Dental Sciences, Bhopal, MP, India 
conducted with an aim to examine the available evidence supporting and refuting the use of social media in communicating with the public during the pandemic outbreaks of an infectious disease, influencing people's behavior, spreading the awareness, and creating or dispelling rumors.

\section{METHODS}

This article followed the Preferred Reporting Items for Systematic Reviews and MetaAnalyses (PRISMA) guidelines [8].

\section{Methodology for Literature Search}

This systematic literature review was synthesized by searching databases such as PUBMED, Google Scholar, and Cochrane Library from 2012 till the year 2019. The keywords "Emerging infectious disease" or "Zika virus" or "Swine flu" or "Nipah virus" or "Ebola virus" or "West Nile virus" or "Bird flu" and "Social media" or "Facebook" or "Twitter" or "YouTube" or "Instagram" were used to retrieve the related studies. The above-mentioned databases are readily available for the literature search.

\section{Inclusion criteria}

The databases were searched for published studies evaluating the utility of social media for various EIDs. The clinical evidence was searched in the form of original peer-reviewed journal articles published in the English language. Clinical and experimental studies were included and the references of the reviewed articles were also searched for the relevant studies wherever necessary to increase the yield.

\section{Exclusion criteria}

Conference papers, book reviews, book chapters, case reports, case series, letters to editors, commentaries, newspaper and newsletter articles, expert opinions, and theses or dissertations were not used. Articles that are not published in English were excluded along with articles that were published prior to January 2012. As before 2012, there were not many articles related to social media use due to the significant changes that have taken place in technology in the 21st century, making these documents to be the most appropriate.

\section{Data Extraction and Management}

Data were independently extracted from the included studies by one author using uniform data extraction and any discrepancies were resolved by discussion. Extracted data were independently entered into an Excel spreadsheet.

\section{Data items extracted}

The following information was extracted from each study:

-The first author of the study, year of publication, number of enrolled patients, type of EID studied, and method of analysis used in the study

-Reported strength, weakness, and recommendations by various studies

-The utility of social media in handing EID.

\section{Statistical Analysis}

The articles were stratified based on the topic studied, the method used, and the major findings. The data obtained was entered in the Microsoft Excel spreadsheet.

Characteristics of the retained studies sorted by the first author name and year of publication were presented in a tabular form. These tables will have information relating to the reported strength, weakness, and recommendations as suggested by various authors of the included studies. Apart from this, we have segregated the studies into various categories based on the application of social media as reported by the studies.

\section{RESULTS}

\section{Comprehensive literature search}

Our search strategy identified 49 studies. A total of 6224 articles were identified from various search engines such as PubMed ( $n=4960$ articles using the search terms-Emerging infectious diseases or Zika virus or Nipah virus or Bird flu virus or Swine flu or Ebola virus or West Nile virus AND social media or Facebook or YouTube or Twitter), Google Scholar ( $n=1167$ article by using the search term- Emerging infectious diseases and social media), and Cochrane library ( $n=97$ articles by using search term- Emerging infectious diseases and social media). Titles were screened first, followed by the screening of abstracts, based on the inclusion and exclusion criteria. A total of 4126 articles were excluded as they were not able to 
provide the full text, were non-peer reviewed, duplicate articles, and articles before 2012 excluded. After excluding those articles, abstract screening of 2098 article was done. After screening, more articles $(n=1983)$ were excluded as they were not fulfilling the inclusion criteria (review articles, letter to editor, comments, and irrelevant articles). A total of 115 papers were retrieved for full text reading. Some articles that were published in non-English language were excluded $(n=66)$. In the end, a total of 49 articles were included in this systematic review. The article inclusion flow diagram is shown in Figure 1

Description of the included studies $(n=49)$ : A significant number of studies along with the literature reviews have evaluated the impact of the social media on EIDs but we restricted our search to only six EIDs (Ebola virus, Nipah virus, Swine flu, Bird flu, West Nile virus and Zika virus). We got 6224 articles on the preliminary search related to the social media and EIDs, out of them, 49 articles were included in the final analysis [9-57]. It was found that most of the articles $(n=15)$ were published in the year 2017 and least in the year $2012(n=1)$. Out of 49 studies, most of the studies were of the Zika virus $(n=24)$ followed by the Ebola virus $(n=15)$ and the least of the Nipah virus $(n=0)$. Distribution of the studies according to the type of EIDs and their year of the publication is shown in Figure 2.

In terms of the types of social media studied, Twitter was undoubtedly the most scrutinized social media platform and was studied in 26 articles, followed by YouTube (6 articles) and Facebook (3 articles). Detailed information about the articles studying each social media application is given in Table 1. The reported strength, weakness, and recommendations of the social media as reported in the included studies are shown in Table 2. The maximum studies included in this systematic review have reported the strengths of social media as compared to the weakness and recommendations.

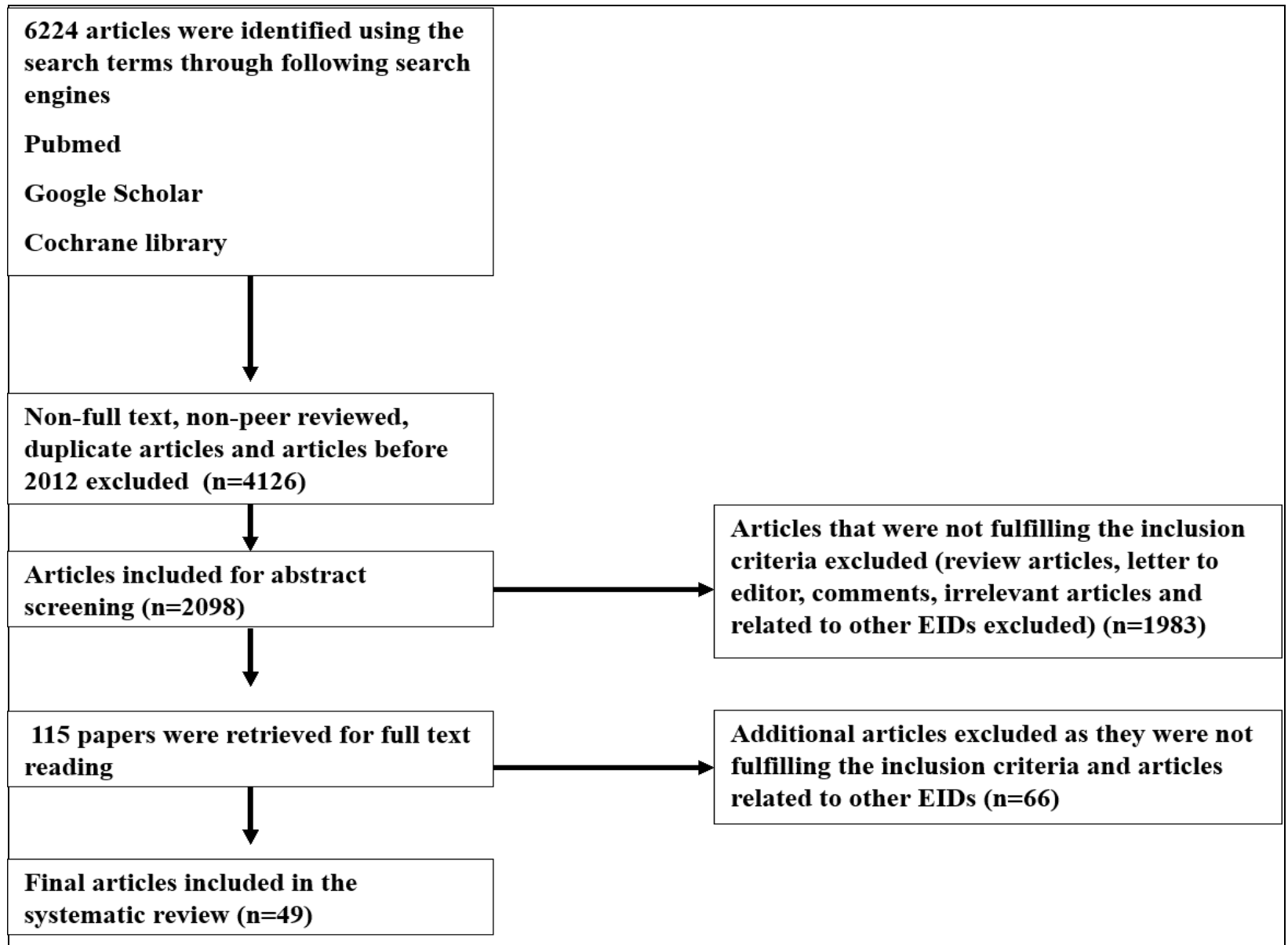

Figure 1. Flow diagram showing the selection process of the articles to be included in systematic review. 
Table 1. Types of social media platform studied $(n=49)$.

\begin{tabular}{|c|c|c|c|}
\hline \multicolumn{2}{|c|}{ Types of social media platform studied } & $\begin{array}{l}\text { No. of } \\
\text { article }\end{array}$ & Studies \\
\hline \multicolumn{2}{|l|}{ Twitter } & 26 & $\begin{array}{l}\text { [9]; [10]; [11]; [12]; [13]; [14]; [15]; [16]; [17]; } \\
\text { [18]; [19]; [20]; [21]; [22]; [23]; [24]; [25]. } \\
\text { [26]. [27]; [28]; [29]; [30]; [31]; [32]; [33]; [34] }\end{array}$ \\
\hline \multicolumn{2}{|l|}{ Facebook } & 03 & [35]; [36]; [37] \\
\hline \multicolumn{2}{|l|}{ YouTube } & 06 & [38]; [39]; [40]; [41]; [42]; [43] \\
\hline \multirow{14}{*}{$\begin{array}{l}\text { Combinations of all } \\
\text { the platforms }\end{array}$} & Twitter and Instagram & \multirow{14}{*}{14} & {$[44]$} \\
\hline & $\begin{array}{l}\text { Twitter,Instagram, Facebook and } \\
\text { YouTube }\end{array}$ & & [45] \\
\hline & Weibo & & {$[46]$} \\
\hline & $\begin{array}{l}\text { Google news, Google trend, Twitter, } \\
\text { YouTube and Wikipedia search } \\
\text { queries. }\end{array}$ & & [47] \\
\hline & $\begin{array}{l}\text { Google searches, Twitter and } \\
\text { microblogs }\end{array}$ & & [48] \\
\hline & Twitter and Google News Trend & & [49] \\
\hline & Pinterest and Instagram & & I[50] \\
\hline & Twitter and Weibo & & [51] \\
\hline & Obstetric practice Web sites & & {$[52]$} \\
\hline & Twitter and facebook & & {$[53]$} \\
\hline & Instagram and Flickr & & {$[54]$} \\
\hline & Instagram & & {$[55]$} \\
\hline & Twitter, Blogs and Delicious & & {$[56]$} \\
\hline & Google Trends & & [57] \\
\hline
\end{tabular}



Figure 2. Distribution of studies according to year of publication and type of EIDs ( $n=49)$ 
Table 2: Characteristics of the studies involved in our systematic review $(n=49)$

\begin{tabular}{|c|c|c|}
\hline Characteristics & Major findings & Studies \\
\hline \multirow{11}{*}{$\begin{array}{l}\text { Reported strengths of social } \\
\text { media }\end{array}$} & $\begin{array}{c}\text { The compared systems showed a good level of } \\
\text { correlation } \\
\text { The social media was more accurate than Traditional } \\
\text { methods }\end{array}$ & $\begin{array}{c}\text { [15]; [19]; [20]; [21] } \\
{[18]}\end{array}$ \\
\hline & $\begin{array}{l}\text { Communication, dissemination of information and } \\
\text { disease prediction }\end{array}$ & $\begin{array}{l}\text { [13]; [14]; [17]; [23]; [29]; [30]; } \\
\text { [35]; [37]; [39]; [40]; [41]; [42]; } \\
\quad \text { [44]; [49]; [50]; [51]; [52] }\end{array}$ \\
\hline & Cost-effective & [38] \\
\hline & Effective medium for health education & [9]; [36]; [45] \\
\hline & Debunking rumors and misinformation & [12]; [28]; [42] \\
\hline & Increases public interest towards the disease & [24]; [32]; [47] \\
\hline & $\begin{array}{l}\text { Utility of analyzing temporal variations in the analytic } \\
\text { triad of locations, actors, and concepts }\end{array}$ & [11] \\
\hline & Web data could improve forecasts & [16]; [33] \\
\hline & $\begin{array}{l}\text { Manages and shares information during the time of } \\
\text { crisis }\end{array}$ & [22]; [27]; 48]; [54]; [56]; [57] \\
\hline & Useful measure of public awareness & [25]; [31]; [46]; [53]; [54] \\
\hline & $\begin{array}{l}\text { Tweets combine information dissemination with } \\
\text { emotional stances and critical views }\end{array}$ & [34] \\
\hline \multirow{6}{*}{$\begin{array}{l}\text { Reported weaknesses of social } \\
\text { media }\end{array}$} & $\begin{array}{l}\text { Should analyze the effectiveness of other social } \\
\text { media also } \\
\text { Source of major potential bias when applying digital } \\
\text { epidemiological methodology to emerging disease } \\
\text { outbreaks }\end{array}$ & [25]; [35]; [44]; [57] \\
\hline & Some sources on social media are outdated & [45] \\
\hline & Has the potential to spread rumors & [12] \\
\hline & $\begin{array}{c}\text { Misguiding posts were more popular than posts } \\
\text { related to information }\end{array}$ & {$[26] ;[36] ;[43]$} \\
\hline & $\begin{array}{l}\text { lack of verification by authorized healthcare } \\
\text { professionals }\end{array}$ & [39] \\
\hline & Inability to evaluate non-English videos. & [15]; [32]; [42] \\
\hline \multirow{3}{*}{$\begin{array}{l}\text { Reported recommendations for } \\
\text { the use of social media }\end{array}$} & $\begin{array}{c}\text { Should primarily support existing traditional methods } \\
\text { Need to develop more tools in future } \\
\text { It is important to }\end{array}$ & $\begin{array}{c}{[9] ;[14] ;[44] ;[47]} \\
{[49]}\end{array}$ \\
\hline & $\begin{array}{c}\text { have quantitative methods to distinguish news from } \\
\text { rumors }\end{array}$ & [26] \\
\hline & $\begin{array}{l}\text { Public health agencies should consider establishing } \\
\text { a larger presence on YouTube to reach more people } \\
\text { with evidence-based information about ZIKV. }\end{array}$ & [42] \\
\hline
\end{tabular}

Table 3: Categorization of the included studies on the basis of their application and methods of analysis $(n=49)$

\begin{tabular}{|c|c|c|c|c|}
\hline Applications of social media & Authors & $\begin{array}{c}\text { Year of } \\
\text { publication }\end{array}$ & $\begin{array}{l}\text { EIDs } \\
\text { studied }\end{array}$ & Method of analysis \\
\hline & [9] & 2015 & \multirow{4}{*}{$\begin{array}{c}\text { Ebola } \\
\text { virus } \\
\text { Zika virus } \\
\text { Zika virus } \\
\text { Influenza } \\
\text { virus } \\
\text { Ebola }\end{array}$} & $\begin{array}{c}\text { Time series analysis (exponential } \\
\text { smoothing) }\end{array}$ \\
\hline & [13] & 2016 & & Content analysis \\
\hline & [14] & 2018 & & Descriptive statistics \\
\hline & [17] & 2015 & & Count based technique \\
\hline & [24] & 2015 & $\begin{array}{l}\text { Ebola } \\
\text { virus }\end{array}$ & Text analysis \\
\hline
\end{tabular}




\begin{tabular}{|c|c|c|c|c|}
\hline \multirow{17}{*}{$\begin{array}{l}\text { Communication purpose, public } \\
\text { health education and dissemination of } \\
\text { the information to the public }\end{array}$} & [28] & 2017 & Zika virus & Network analysis \\
\hline & [29] & 2016 & Zika virus & $\begin{array}{l}\text { volumetric and text mining } \\
\text { analysis }\end{array}$ \\
\hline & {$[30]$} & 2019 & $\begin{array}{l}\text { Ebola } \\
\text { virus }\end{array}$ & Descriptive statistics \\
\hline & [33] & 2019 & Zika virus & Bootstrap resampling \\
\hline & {$[34]$} & 2018 & Ebola & $\begin{array}{c}\text { Quantitative and qualitative } \\
\text { analysis }\end{array}$ \\
\hline & [35] & 2018 & Zika virus & Descriptive statistics \\
\hline & [36] & 2016 & Zika virus & Descriptive statistics \\
\hline & [39] & 2013 & $\begin{array}{l}\text { West Nile } \\
\text { virus }\end{array}$ & $\begin{array}{l}\text { Inter-rater agreement using } \\
\text { Cohen's kappa }\end{array}$ \\
\hline & [40] & 2015 & $\begin{array}{l}\text { Ebola } \\
\text { virus }\end{array}$ & $\begin{array}{c}\text { Student t-test and Chi-squared } \\
\text { test }\end{array}$ \\
\hline & [41] & 2015 & $\begin{array}{l}\text { Ebola } \\
\text { virus }\end{array}$ & $\begin{array}{l}\text { Descriptive analysis and Kruskal- } \\
\text { Wallis one way analysis }\end{array}$ \\
\hline & [42] & 2017 & Zika virus & $\begin{array}{l}\text { Kruskal-Wallis } \mathrm{H} \text {-test and } \\
\text { Wilcoxon rank sum test }\end{array}$ \\
\hline & [45] & 2017 & Zika virus & $\begin{array}{c}\text { Chi-square test or Fisher's exact } \\
\text { test }\end{array}$ \\
\hline & [46] & 2013 & $\begin{array}{l}\text { Bird flu } \\
\text { (H7N9) }\end{array}$ & $\begin{array}{l}\text { Paired t test for comparing } \\
\text { between baseline and peak }\end{array}$ \\
\hline & [49] & 2016 & $\begin{array}{l}\text { Ebola } \\
\text { virus }\end{array}$ & Descriptive statistics \\
\hline & {$[50]$} & 2017 & Zika virus & $\begin{array}{c}\text { Chi-squared test and Fisher's } \\
\text { exact test }\end{array}$ \\
\hline & {$[52]$} & 2017 & Zika virus & Descriptive statistics \\
\hline & [54] & 2015 & $\begin{array}{l}\text { Ebola } \\
\text { virus }\end{array}$ & Descriptive statistics \\
\hline \multirow{10}{*}{$\begin{array}{l}\text { Influence public or viewer's behavior } \\
\text { and assess the public's response } \\
\text { towards EIDs }\end{array}$} & [10] & 2015 & $\begin{array}{l}\text { Ebola } \\
\text { virus }\end{array}$ & \multirow{3}{*}{$\begin{array}{l}\text { Mathematical modeling and time } \\
\text { series analysis } \\
\text { Tenfold cross-validation } \\
\text { quantitative and qualitative conten } \\
\text { analysis }\end{array}$} \\
\hline & {$[15]$} & 2017 & Zika virus & \\
\hline & {$[25]$} & 2017 & Zika virus & \\
\hline & [27] & 2016 & Zika virus & Text analysis and mining \\
\hline & [31] & 2017 & Zika virus & Content analysis \\
\hline & [32] & 2019 & Zika virus & Data Annotation Analysis \\
\hline & [38] & 2015 & $\begin{array}{l}\text { Ebola } \\
\text { virus }\end{array}$ & $\begin{array}{c}\text { Unpaired Student t test and } \\
\text { multivariate logistic regression } \\
\text { analysis }\end{array}$ \\
\hline & {$[47]$} & 2017 & Zika virus & Multivariate regression method \\
\hline & [53] & 2019 & $\begin{array}{l}\text { Ebola } \\
\text { virus }\end{array}$ & Inductive thematic analysis \\
\hline & {$[55]$} & 2017 & Zika virus & Retrospective analysis \\
\hline \multirow{6}{*}{$\begin{array}{l}\text { Predict an epidemic and disease } \\
\text { surveillance }\end{array}$} & [11] & 2017 & Zika virus & $\begin{array}{l}\text { Spatiotemporal and network } \\
\text { analysis tools }\end{array}$ \\
\hline & {$[16]$} & 2014 & $\begin{array}{l}\text { Influenza } \\
\text { virus }\end{array}$ & Basic linear autoregressive model \\
\hline & [18] & 2012 & $\begin{array}{l}\text { Influenza } \\
\text { virus }\end{array}$ & $\begin{array}{c}\text { Quantitative spatio-temporal } \\
\text { analysis. }\end{array}$ \\
\hline & [19] & 2013 & $\begin{array}{l}\text { Influenza } \\
\text { virus }\end{array}$ & $\begin{array}{l}\text { Pearson correlation coefficients } \\
\text { and z-test }\end{array}$ \\
\hline & {$[20]$} & 2015 & $\begin{array}{l}\text { Influenza } \\
\text { virus }\end{array}$ & Multivariate and univariate tests \\
\hline & [21] & 2013 & $\begin{array}{l}\text { Influenza } \\
\text { virus }\end{array}$ & Pearson correlation coefficient \\
\hline
\end{tabular}




\begin{tabular}{|c|c|c|c|c|}
\hline & [22] & 2016 & Bird flu & $\begin{array}{l}\text { Intercoder reliability using Cohen's } \\
\text { kappa }\end{array}$ \\
\hline & [23] & 2015 & $\begin{array}{l}\text { Ebola } \\
\text { virus }\end{array}$ & $\begin{array}{l}\text { Bivariate inferential statistics, } \\
\text { Content analysis and intraclass } \\
\text { correlation coefficients }\end{array}$ \\
\hline & [37] & 2017 & Zika virus & $\begin{array}{l}\text { Inter-rater agreement using } \\
\text { Cohen's kappa }\end{array}$ \\
\hline & [44] & 2017 & $\begin{array}{l}\text { Ebola } \\
\text { virus }\end{array}$ & Content analysis \\
\hline & [48] & 2017 & Zika virus & Pearson's correlation \\
\hline & {$[51]$} & 2016 & $\begin{array}{l}\text { Ebola } \\
\text { virus }\end{array}$ & Descriptive statistics \\
\hline & {$[56]$} & 2013 & $\begin{array}{l}\text { Influenza } \\
\text { virus }\end{array}$ & Descriptive analysis \\
\hline & [57] & 2017 & Zika virus & Spearman's rank correlation \\
\hline \multirow{3}{*}{$\begin{array}{l}\text { Helps in spreading and debunking } \\
\text { rumors and misinformation, therefore } \\
\text { authentication is necessary }\end{array}$} & [12] & 2018 & Zika virus & $\begin{array}{l}\text { Content and social network } \\
\text { analysis }\end{array}$ \\
\hline & [26] & 2014 & $\begin{array}{l}\text { Ebola } \\
\text { virus }\end{array}$ & Quantative analysis \\
\hline & [43] & 2018 & Zika virus & $\begin{array}{l}\text { Quantitative analysis and multiple } \\
\text { logistic regression }\end{array}$ \\
\hline
\end{tabular}

\section{DISCUSSION}

The present systematic review was conducted to evaluate the pros and cons of social media in detecting the pandemic outbreaks of infectious diseases like Zika, Ebola, Swine flu, Bird flu, West Nile, and Nipah virus.

The very first disease studied under this systematic review was Ebola hemorrhagic fever and almost 15 articles of this infectious disease were included in our systematic review. The second EID included in our systematic review was the Zika virus whose first outbreak was reported from the Island of Yap in 2007 [58]. We have included 24 studies of Zika virus infection in our systematic review.

Influenza outbreak (H1N1) or Swine flu disease was first identified in Mexico in April 2009 [59]. A total of 07 studies of Swine flu were included. Nipah virus is a zoonotic virus that causes a range of illnesses from asymptomatic (subclinical) infection to acute respiratory illness and fatal encephalitis. Since the outbreak of the Nipah virus is very recent and occurred in 2018, we could not find any articles related to social media and the Nipah virus.

Bird flu or Avian Influenza is caused by the Influenza bird flu virus subtypes A (H5N1) and A (H9N2). The natural hosts for spreading the avian influenza disease are the birds. We have included 2 articles of Bird flu in our systematic review. The last disease included in our systematic review is West Nile caused by the West Nile virus (WNV). Approximately, $80 \%$ of the people who are infected will not show any symptoms. The largest outbreaks occurred in Greece, Israel, Romania, Russia and USA [60]. Unfortunately, we could not get many articles related to West Nile disease; hence, only 1 article was included.

To provide a systematic overview of these studies, we have segregated these studies under four categories on the basis of their application and evaluated them in terms of the EIDs studied, year of publication and method of analysis used (Table 3 ). The four categories are:

\section{Category 1: Communication purpose, public health education and dissemination of the information to the public}

In recent years, social media has become a major source of public health education, communication, and help in disseminating recent evidence-based information. Most of the journal articles $(n=22)$ on this topic used social media for the purpose of communication and providing information to the public for EIDs. In 2016, Fu and fellow-researchers studied data related to the Zika virus with the help of Twitter and concluded that Twitter can be a preferred channel for communication as opposed to the government sites [13]. Wong $R$ et al concluded that Twitter has become the most commonly used communication tool frequently used by 
many local health departments to respond to novel outbreaks [23].

YouTube can be used as a significant source of information related to West Nile virus infection and should be used by various healthcare agencies but at the same time, the authors commented on the drawback of the medium as it lacks authentication and so should be used cautiously [39].

\section{Category 2: Influence public or viewer's behavior and assess the public's response towards EIDs}

Nowadays, researchers have started to estimate the public interest and response towards any disease on the basis of number or post or messages on social media. The number of social media messages about a disease in a certain time period predicts the interest of an individual towards it. Ten articles were included in this category. Monitoring information dissemination trends on social media can be a effective way of understanding the general public's interests and concerns [25]. Nagpal S et al. used YouTube video as a source of presenting clinical symptoms of infectious diseases (Ebola disease) during the epidemics, and found that these should be included in the high relevance group as it has the power to influence the viewer's behavior [38]. Seltzer EK et al. concluded that image-sharing platforms can be used for the purpose of assessing public fears and misinformation, providing awareness interventions and information exchange about public health crises, like Ebola [54].

\section{Category 3: Predict an epidemic and disease surveillance}

Social media allows the health agencies to guide the public during surveillance of an EID. In this category, 14 articles were included. According to a study, twitter can reduce forecasting error by $17-30 \%$ over a baseline that only uses historical data [16]. Twitter may allow the detection of disease outbreaks through analysis of data generated by social media [17]. Twitter data can act as a supplementary indicator to gauge influenza infection [18], the high correlation coefficient was found between the trend of our influenza-positive tweets and Influenza likeillness (ILI) trends identified by US traditional surveillance systems [19].
Twitter data is able to detect moderately small outbreaks within a few days and for large outbreaks within hours [20]. Vos SC et al. [22] concluded that tweets related to disease outbreak contained efficacy information that would help individuals to cope up with the crisis. However, social media still cannot be used as an effective platform for distributing information that could contribute to an appropriate response.

\section{Category 4: Helps in spreading and debunking rumors and misinformation}

Information about EIDs on social media is not always accurate or useful because it is usergenerated. In this category, three articles were included. Pathak $\mathrm{R}$ et al. in their study demonstrated that the majority of the internet videos about Ebola on YouTube were characterized as useful [40].

Social media is becoming the dominant source of information on emerging diseases, their effects on public health measures remain uncertain. Apart from the benefits, there are certain drawbacks of social media that can misguide the users as reported by the studies included in our systematic review. According to Towers et al. [10], social media is a major source of potential bias. Chandrasekaran et al. [45] reported that some sources on social media are outdated. Wood MJ revealed that social media has the potential to spread rumors [12].

According to Sharma et al., misguiding posts were more popular than posts related to information [36]. Tang $L$ et al. concluded that social media lacked "theorization" and "methodologic rigor" and found that approximately $20 \%-30 \%$ of the YouTube videos about EIDs contain inaccurate or misleading information [61]. Oyeyemi $S$ et al. found that more than half of the tweets $(58.9 \%)$ were inaccurate and contained misinformation regarding the Ebola virus disease [62]. Brownstein JS et al. concluded that the information available from the Internet is evergrowing but lacks sensitivity, specificity, and may not be reliable [63]. Owing to the abovementioned drawbacks, certain steps should be taken by the government and public health professionals to evaluate the reliability and validity of social media information. The coverage of social media would be better if media organizations start designating health 
reporters who are familiar with the subject and issues. Although, social media is a powerful surveillance channel, public health professionals and government institutions must use it with caution.

This study has also some limitations. Although we performed an extensive literature search, several pitfalls do exist in our study. Firstly, we have only included the articles published in the English language. Secondly, we have limited our search only to six EIDs owing to the fact that there are a number of EIDs. Since we cannot include all of them in our systematic review, we have randomly chosen six EIDs. Lastly, there are various synonyms of EIDs such as communicable diseases or transmissible diseases but we have only included EIDs as search term in various search engines which might alter the results and introduce bias in the systematic review. Hence, the above-mentioned points should be kept in mind while performing further systematic reviews on this vital topic.

\section{CONCLUSION}

As social media has become a powerful communication channel, social media sites are on the rise with the emergence of EIDs. Enough pieces of evidence are present in the literature favoring the use of social media as a medium to disseminate information. The present review also supports the use of social media as an important medium for clinicians, public health practitioners, and non-professionals seeking health information for the detection of EIDs. Since social media do not have the capacity to replace traditional systems of gathering information about a disease, they should primarily support the existing traditional methods and be viewed as an extension of the traditional system rather than an alternative.

\section{ACKNOWLEDGMENTS}

Declaration of Conflicting Interests: The authors declare that they have no conflict of interest.

\section{Funding: Not applicable \\ REFERENCES}

1. Obar JA, Wildman S. Social media definition and the governance challenge: An introduction to the special issue. Telecomm Policy 2015; 39: 745-50.
2. O'Connell EK, Zhang GY, Leguen F, Llau A, Rico E. Innovative uses for syndromic surveillance. Emerg Infect Dis 2010; 16: 669-71.

3. Lederberg J, Shope RE, Oaks SC. Emerging infection: microbial threats to health in the United States. Washington (DC): National Academy Press; 1992.

4. Jones KE, Kate NG, Levy MA, et al. Global trends in emerging infectious diseases. Nature 2008; 451 (7181): 990-993.

5. Biswas M. Health organizations' use of social media tools during a pandemic situation: an $\mathrm{H} 1 \mathrm{~N} 1$ flu context. J New Commun Res 2013; 5: 46-81.

6. World Health Organisation-SEARO. (2011). Developing tools for strategic communication to the media on emerging infectious diseases (EIDs). Retrieved February 26, 2019 from: http://apps.searo.who.int/PDS_DOCS/B4803.pdf.

7. Korda $H$, Itani Z. Harnessing social media for health promotion and behavior change. Health Promot Pract. 2013; 14: 15-23.

8. Moher D, Liberati A, Tetzlaff J, Altman DG. The PRISMA Group. Preferred Reporting Items for Systematic Reviews and Meta-Analyses: The PRISMA Statement. PLoS Med. 2009; 6(7): e1000097.

9. Odlum M, Yoon S. What can we learn about the Ebola outbreak from tweets? Am J Infect Control. 2015; 43(6): 563-571.

10. Towers S, Afzal S, Bernal G, et al. Mass Media and the Contagion of Fear: The Case of Ebola in America. PLoS ONE 2015;10(6):e0129179.

11. Stefanidis A, Vraga E, Lamprianidis G, et al. Zika in Twitter: Temporal Variations of Locations, Actors, and Concepts. JMIR Public Health Surveill 2017;3(2): e22.

12. Wood MJ. Propagating and Debunking Conspiracy Theories on Twitter during the 20152016 Zika Virus Outbreak. Cyberpsychol Behav Soc Netw. 2018; 21(8): 485-90.

13. Fu K, Liang H, Saroha N, Tse Z, Ip P, Fung I. How people react to Zika virus outbreaks on Twitter? A computational content analysis. Am J Infect Control. 2016; 44(12): 1700-1702.

14. Vijaykumar S, Nowak G, Himelboim I, Jin Y. Virtual Zika transmission after the first U.S. case: who said what and how it spread on Twitter. Am J Infect Control. 2018; 46: 549-57.

15. Miller M, Banerjee T, Muppalla R, Romine W, Sheth A. What Are People Tweeting About Zika? An Exploratory Study Concerning Its Symptoms, Treatment, Transmission, and Prevention. JMIR Public Health Surveill. 2017; 3(2): e38. 
16. Paul MJ, Dredze M, Broniatowski D. Twitter Improves Influenza Forecasting. PLoS Curr. 2014; 1: 1-12.

17. Jain VK, Kumar S. An effective approach to track levels of influenza-A (H1N1) pandemic in India using twitter. Procedia Computer Science. 2015; 70: $801-807$.

18. Achrekar H, Gandhe A, Lazarus R, Yu SH, Liu B. Twitter improves seasonal influenza prediction. Science and Technology Publications 2012: 1-10

19. Gesualdo F, Stilo G, Agricola E, Gonfiantini MV, Pandolfi $E$, et al. Influenza-Like Illness Surveillance on Twitter through Automated Learning of Naïve Language. PLoS ONE. 2013;8(12): e82489.

20. Sparks R, Cameron M, Woolford S, et al. Syndromic Surveillance using Twitter Data. Emer Med. 2015; 5(3): 1000254.

21. Broniatowski DA, Paul MJ, Dredze M. National and Local Influenza Surveillance through Twitter: An Analysis of the 2012-2013 Influenza Epidemic. PLoS ONE 2013; 8(12): e83672.

22. Vos SC, Buckner MM. Social Media Messages in an Emerging Health Crisis: Tweeting Bird Flu. J Health Commun. 2016; 21(3): 301-308

23. Wong R, Harris. JK, Staub M, Bernhardt JM. Local Health Departments Tweeting About Ebola: Characteristics and Messaging. J Public Health Manag Pract. 2015; 23(2): e16-e24

24. Lazard AJ, Scheinfeld MA, Bernhardt JM, Wilcox GB, Suran M. Detecting themes of public concern: A text mining analysis of the centers of Disease Control and prevention's Ebola live twitter chat. Am J Infect Control. 2015; XXX: 1-3

25. Gui X, Wang Y, Kou Y, Reynolds TL, Chen Y, Mei M. Understanding the Patterns of Health Information Dissemination on Social Media during the Zika Outbreak. AMIA Annu Symp Proc. 2017: 820-829

26. Jin F, Wang W, Zhao L, et al. Misinformation Propagation in the Age of Twitter. IEEE Computer Society $2014 ; 1-7$

27. Glowacki EM, Lazard AJ, Wilcox GB, Mackert M, Bernhardt JM. Identifying the public's concerns and the Centers for Disease Control and Prevention's reactions during a health crisis: An analysis of a Zika live Twitter chat. Am J Infect Control. 2016; 34-38

28. Hagen L, Keller T, Neely S, DePaula N, RobertCooperman C. Crisis Communications in the Age of Social Media: A Network Analysis of ZikaRelated Tweets. Social Science Computer Review. 2017; 1-19

29. Khatua A, Khatua A. Immediate and Long-term Effects of 2016 Zika Outbreak: A Twitter-based Study. IEEE 18th International Conference on e-
Health Networking, Applications and Services 2016;1-8

30. Liang $\mathrm{H}$, Fung ICH, Tse ZTH, Yin J, Chan $\mathrm{CH}$, Pechta LE, et al. How did Ebola information spread on twitter: broadcasting or viral spreading?. BMC Public Health. 2019; 19:438

31. Gallivan M, Oppenheim B, Madhav NK. Using social media to estimate Zika's impact on tourism: \#babymoon, 2014-2017. PLoS ONE. 2019;14(2):e0212507

32. Mamidi R, Miller M, Banerjee T, Romine W, Sheth A. Identifying Key Topics Bearing Negative Sentiment on Twitter: Insights Concerning the 2015-2016 Zika Epidemic. JMIR Public Health Surveill. 2019; 5(2): e11036.

33. Daughton AR, Paul MJ. Identifying Protective Health Behaviors on Twitter: Observational Study of Travel Advisories and Zika Virus. J Med Internet Res. 2019; 21(5): e13090.

34. Morin C, Bost I, Mercier A, Dozon J, Atlani-Duault L. Information Circulation in times of Ebola: Twitter and the Sexual Transmission of Ebola by Survivors. PLOS Curr. 2018. Edition 1. doi: 10.1371 /currents.outbreaks.4e35a9446b89c1b46f 8308099840d48f.

35. Lwin M, Jiahui Lu, Sheldenkar A, Schulz $P$. Strategic Uses of Facebook in Zika Outbreak Communication: Implications for the Crisis and Emergency Risk Communication Model. Int $\mathrm{J}$ Environ Res Public Health.. 2018; 15: 1974.

36. Sharma M, Yadav K, Yadav N, Ferdinand K. Zika virus pandemic - analysis of Facebook as a social media health information platform. Am J Infect Control. 2016; 45: 301-2.

37. Vijaykumar S, Meurzec R, Jayasundar K, Pagliari $\mathrm{C}$, Fernandopulle $\mathrm{Y}$. What's buzzing on your feed? Health authorities' use of Facebook to combat Zika in Singapore. J Am Med Inform Assoc. 2017; 24(6): 1155-1159.

38. Nagpal S, Karimianpour A, Mukhija D, Mohan D, Brateanu A. YouTube videos as a source of medical information during the Ebola hemorrhagic fever epidemic. SpringerPlus. 2015; 4:457.

39. Dubey D, Amritphale A, Sawhney A, Dubey D, Srivastav. N. Analysis of YouTube as a Source of Information for West Nile Virus Infection. Clin Med Res. 2013;12(3-4): 129-132

40. Pathak R, Poudel DR, Karmacharya P, et al. YouTube as a Source of Information on Ebola Virus Disease. N Am J Med Sci. 2015; 7(7): 306-9

41. Basch $\mathrm{CH}$, Basch CE, Ruggles KV, Hammond R. Coverage of the Ebola Virus Disease Epidemic on YouTube. Disaster Med Public Health Prep.2015; 9(5): 531-35

42. Basch $\mathrm{CH}$, Fung $\mathrm{ICH}$, Hammond $\mathrm{RN}$, et al. Zika Virus on YouTube: An Analysis of English- 
language Video Content by Source. J Prev Med Public Health 2017; 50:133-140

43. Boraa K, Dasb D, Barmand B, Borahe P. Are internet videos useful sources of information during global public health emergencies? A case study of YouTube videos during the 2015-16 Zika virus pandemic. Pathog Glob Health. 2018; 112 (6): 320-328

44. Guidrya J, Jinb Y, Orrc C, Messnera M, Meganck S. Ebola on Instagram and Twitter: How health organizations address the health crisis in their social media engagement. Public Relations Review. 2017; 43: 477-486.

45. Chandrasekaran N, Gressick K, Singh V, Kwal J, Cap N, Sengul T, et al. The Utility of Social Media in Providing Information on Zika Virus. Cureus. 2017; 9(10): e1792.

46. Fung $\mathrm{ICH}$, Fu KW, Ying $\mathrm{Y}$, et al. Chinese social media reaction to the MERS-CoV and avian influenza $A(H 7 N 9)$ outbreak. Infect Dis Poverty. 2013; 2:31-43

47. Bragazzi NL, Alicino C, Trucchi C, et al. Global reaction to the recent outbreaks of Zika virus: Insights from a Big Data analysis. PLoS ONE 2017; 12(9): e0185263.

48. McGough SF, Brownstein JS, Hawkins JB, Santillana M. Forecasting Zika Incidence in the 2016 Latin America Outbreak Combining Traditional Disease Surveillance with Search, Social Media, and News Report Data. PLoS Negl Trop Dis. 2017; 11(1): e0005295.

49. Househ M. Communicating Ebola through social media and electronic news media outlets: A crosssectional study. Health Informatics J. 2016; 22(3): 470-8.

50. Fung ICH, Blankenship EB, Goff M, et al. ZikaVirus-Related Photo Sharing on Pinterest and Instagram. Disaster Med Public Health Prep. 2017; $1-3$

51. Fung ICH, Fu KW, Chan $\mathrm{CH}$, et al. Social Media's Initial Reaction to Information and Misinformation on Ebola, August 2014: Facts and Rumors. Public Health Rep. 2016; 131: 461-73

52. Lehnert JD, Ellingson MK, Goryoka GW, Kasturi R, Maier E, Chamberlain AT. Use of Obstetric Practice Web Sites to Distribute Zika Virus Information to Pregnant Women During a Zika Virus Outbreak. J Public Health Manag Pract. 2017; 23(6): 608-613

53. Roy M, Moreau N, Rousseau C, Mercier A, Wilson A, Duault LA. Ebola and Localized Blame on Social Media: Analysis of Twitter and Facebook Conversations During the 2014-2015 Ebola Epidemic. Cult Med Psychiatry. 2019. https://doi.org/10.1007/s11013-019-09635-8
54. Seltzer EK, Jean NS, Golinkoff EK, Asch DA, Merchant RM. The content of social media's shared images about Ebola: A retrospective study. Public Health. 2015; 129: 1273-1277

55. Seltzer EK, Martz EH, Merchant MA. Public sentiment and discourse about Zika virus on Instagram. Public Health. 2017; 150: 170-75

56. Freberg K, Palenchar MJ, Veil SR. Managing and sharing $\mathrm{H} 1 \mathrm{NI}$ crisis information using social media bookmarking services. Public Relations Review 2013; 39: 178-184

57. Adebayo G, Neumark Y, Edelsburg AG, Ahmad WA, Levine $H$. Zika pandemic online trends, incidence and health risk communication: a time trend study. BMJ Glob Health. 2017;3:e000296.

58. World Health Organisation. The history of Zika virus. Retrieved February 27, 2019 from: https://www.who.int/emergencies/zikavirus/timeline/en/.

59. National Health Service. Swine flu. Retrieved February 24, 2019 from https://www.nhs.uk/conditions/swine-flu/.

60. World Health Organisation. West Nile virus. Retrieved May 08, 2019 from: https://www.who.int/news-room/factsheets/detail/west-nile-virus

61. Tang L, Bie B, Park S, Zhi D. Social media and outbreaks of emerging infectious diseases: A systematic review of literature. Am J Infect Control. 2018; 46(9): 962-972.

62. Oyeyemi S, Gabarron E, Wynn R. Ebola, Twitter, and misinformation: a dangerous combination? BMJ. 2014; 349: g6178.

63. Brownstein JS, Freifeld CC, Madoff LC. Digital disease detection-harnessing the Web for public health surveillance. N Engl J Med. 2009; 360(21): 2153-2157. 